DOI: http://dx.doi.org/10.33846/hn40501

http://heanoti.com/index.php/hn

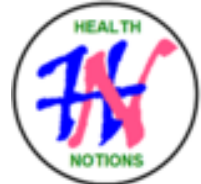

RESEARCH ARTICLE

URL of this article: http://heanoti.com/index.php/hn/article/view/hn40501

\title{
The Factors of Cronic Kidney Disease (CKD) on Public Transportation Drivers in
} Jember Regency

\author{
Novita Firdaus $^{1(\mathrm{CA})}$, Hadi Prayitno ${ }^{2}$, Isa Ma'rufi ${ }^{3}$ \\ ${ }^{1(\mathrm{CA})}$ Post Graduate School of Publich Health Science, Universitas Jember, Indonesia; \\ novitafirdaus14@gmail.com (Corresponding Author) \\ ${ }^{2}$ Department of Sosial Walfare Science, Faculty of Social Science and Political Science, Universitas Jember, \\ Indonesia; hprayitno29@yahoo.co.id \\ ${ }^{3}$ Department of Enviromental Health, Faculty of Publich Health, Universitas Jember, Indonesia; \\ isa.marufi@gmail.com
}

\begin{abstract}
Chronic kidney disease (CKD) is a condition where the kidneys cannot filter waste properly as indicated by the estimated Glomerular Filtration Rate (eGFR) $<60 \mathrm{~mL} / \mathrm{min} / 1.73 \mathrm{~m}^{2}$, which caused by various factors such as infection, tumors, congenital abnormalities, degenerative diseases and others, while the results of observations of preliminary studies conducted by researchers in August 2019 namely lead particles were possible to enter the driver's body through inhalation pathways, ingestion with behavior hand to mouth and without washing hands first and also absorption through the skin was found in drivers who do not wear clothing that covers the entire skin. Interviews found that $65 \%$ of 131 public transportation drivers in Jember had a habit of consuming drinking water $<8$ glasses / day and most of them had smoking habits, based on the theory that both habits are known to worsen kidney conditions. The research design in this study was cross sectional with sample size of 34 respondents, selecting by cluster and proportional random sampling. Data were analyzed using multiple logistic regression test. The factor that most influence the incidence of CKD on public transportation drivers in Jember Regency was physical workload. Suggestions for public transportation drivers in Jember Regency to limit physical workload so that the physical workload is not heavy, drink> 8 glasses of water a day, maintain nutritional status in the normal category, reduce smoking or stop smoking, and stop drinking alcohol
\end{abstract}

Keywords: chronic kidney disease; public transportation driver

\section{INTRODUCTION}

\section{Background}

Air Pollution Standard Index (ISPU) on 3 September 2019 indicate that some urban areas in Indonesia has reduced air quality ranging from moderate to unhealthy ${ }^{1}$ The results of the analysis of ambient air quality of the lead parameters in Jember Regency in 2018 in several locations were $<0.0008 \mu \mathrm{g} / \mathrm{Nm}^{3}$. The lead content contained in gasoline causes the resulting emissions pose a serious threat to the global public health status due to the toxic nature of lead ${ }^{(1)}$.

The route of lead exposure on the body of public transportation drivers is through inhalation, ingestion, absorption through the skin, and absorption from leaded foreign bodies. The slow absorption of lead in the body results in $>90 \%$ of lead spreading through the blood and distributed to the brain, liver, kidneys, and stored in the bones and teeth and accumulates over time ${ }^{(3)}$. The triggering factor of CKD is due to work factors that unconsciously can affect unhealthy lifestyles such as the habit of consuming drinks or supplements to prevent fatigue, the onset of stress due to targets that have to be achieved, even lack of drinking water ${ }^{(3)}$. 
Roina \& Megawati mentioned, someone with an older age is more at risk of suffering from CKD, this is due to a decrease in estimated Glomerular Filtration Rate (eGFR) which is a process of normal anging ${ }^{(4)}$. The kidneys cannot regenerate new nephrons, when the kidneys experienceangingthere is a decrease in the number of nephrons. Lead is a dangerous metal found in tobacco and tobacco smoke, so smoking is one of the factors that can lead to an accumulation of lead in the blood which is higher than non-smokers. Alcoholic drinks cause fatty liver or fatty liver which results in the disruption of detoxification of toxins which can then damage the kidneys ${ }^{(5)}$.

Means of public transportation in Jember Regency are most often found because the most economical rates, through many routes and only operate in the Jember Regency The results of observations in a preliminary study conducted by researchers on public transportation drivers in Jember in August 2019 namely, lead particles are possible enter the body of the public transport driver through the inhalation route by breathing leadcontaminated air, ingestion withbehavior hand-to-mouth by consuming food and drinks that have been exposed to lead and without washing hands first, and also absorption through the skin is found in drivers who do not use clothes that cover the entire skin.

\section{Purpose}

The purpose of this study is to analyze the risk factors forincidents Chronic Kidney Disease (CKD) in public transportation drivers. Measuring the physical workload of public transportation drivers. Measuring the level of drinking water consumption in public transportation drivers. Measuring the level of dehydration of public transportation drivers in Jember district.

\section{METHODS}

This research method was observational analytic with quantitative approach. Observational analytic research conducted by observing without giving treatment to the research object. The research design used in this study was cross-sectional. Retrieval of physical workload data, drinking water consumption level, dehydration rate, disease history, individual characteristics, blood lead levels, blood albumin levels, and status as Chronic Kidney Disease (CKD) seen from the eGFR value based on examination of creatinine levels in the blood in blood yellow lynd public transportation drivers association in Jember Regency in August 2019December 2019. Data were analyzed using multiple logistic regression test.

\section{RESULTS}

Table 1 is a translation of the results of the simple logistic regression analysis and the p-value of $<0.25$ were included in the category of eligible and can be included in the multiple logistic regression test.

Tabel 1. Results of simple logistic regression test

\begin{tabular}{|c|c|c|c|c|}
\hline \multirow{2}{*}{ Variable } & \multirow{2}{*}{ Factors } & \multirow{2}{*}{ p-value } & \multicolumn{2}{|c|}{ Multivariate test } \\
\hline & & & Qualify & Ineligible \\
\hline Physical workloads & Physical workloads & 0.012 & $\sqrt{ }$ & \\
\hline Drinking water consumption & Drinking water consumption level & 0.035 & $\sqrt{ }$ & \\
\hline Level of dehydration & Level of dehydration & 0.026 & $\sqrt{ }$ & \\
\hline \multirow[t]{3}{*}{ Disease history } & Diabetes melitus & 0.005 & $\sqrt{ }$ & \\
\hline & Systolic blood pressure & 0.013 & $\sqrt{ }$ & \\
\hline & Distolic blood pressure & 0.011 & $\sqrt{ }$ & \\
\hline \multirow[t]{7}{*}{ Individual characteristics } & Age & 0.042 & $\sqrt{ }$ & \\
\hline & Working period & 0.999 & & $\sqrt{ }$ \\
\hline & Nutritional status & 0.016 & $\sqrt{ }$ & \\
\hline & Skinfold thickness & 0.057 & $\sqrt{ }$ & \\
\hline & Physical Activity & 0.022 & $\sqrt{ }$ & \\
\hline & Smoking habit & 0.039 & $\sqrt{1}$ & \\
\hline & Alcohol consumption habits & 0.027 & $\sqrt{ }$ & \\
\hline Blood lead level & Blood lead level & 0.227 & $\sqrt{1}$ & \\
\hline Albumin levels in the blood & Albumin levels in the blood & 0.999 & & $\sqrt{ }$ \\
\hline
\end{tabular}


Factors that fall into the category of qualifying in Table 1 were included in the multiple logistic regression test using the method of backward wald, then variables that had no effect will be eliminated automatically and in step 1 which can be seen in Table 2 had found the most influential factor on the incidence of CKD on public transportation drivers in Jember Regency.

Tabel 2. The factor that most influence the incidence of CKD on public transportation drivers in Jember Regency

\begin{tabular}{cccccc}
\hline Step & Factor & B & Wald & Sig. & Exp(B) \\
\hline Step $1^{\text {a }}$ & Physical workloads & 3.640 & 6.282 & 0.012 & 38.092 \\
& Constant & -7.037 & 10.048 & 0.002 & 0.001 \\
\hline
\end{tabular}

Table 2 shows that, the factors that most influence the incidence of CKD on public transportation drivers in Jember Regency was physical workload. This was due in step 1, the physical workload factor had the highest risk of 38.092 compared to other factors that had been eliminated automatically in the multivariate model with multiple logistic regression tests. The magnitude of risk was 38.092, which means that drivers with moderate physical workload have a risk of 38.092 times more likely to suffer CKD compared to drivers with physical workloads with normal and light categories, conversely, physical workloads with normal and light categories will reduce the risk of CKD occurring public transportation driver in Jember Regency.

\section{DISCUSSION}

The results of the study indicate that there is an influence of physical workload on the incidence of CKD on public transportation drivers in Jember Regency. The results of this study are in line with research conducted by Raputra which states that, the lighter the physical workload of workers, the lower the dehydration rate ${ }^{(6)}$. The results of the cross tabulation in this study showed that, most of the drivers who had physical workloads in the moderate category aged 40-59 years $(66.7 \%)$ and most of the drivers who had physical workloads in the moderate category were drivers who had physical activity with mild category $(66.7 \%)$, while most drivers who have physical activity with mild category also suffer from severe dehydration or lack of fluids $(50.0 \%)$.

The results of the study prove that there is an influence on the level of dehydration with the incidence of CKD on public transportation drivers in Jember Regency. The results of this study are in line with research conducted by Yusuf et al. which states that, the heavier the level of dehydration, the higher the risk of kidney dysfunction $^{(7)}$. The results showed that most of the drivers with CKD experienced dehydration in the category of lack of fluid or severe dehydration which was marked by the concentrated color of the urine of the driver in the range of numbers 7-8 in the urine color parameters. Kozier et al. states, in patients with CKD the aging process can cause normal changes that have the potential to increase the risk of dehydration, dehydration can be caused by a lack of response to the thirst that is felt so that antidiuretic hormone levels are still in the normal range or even increase but there is a decrease in the ability of nephrons to store water as an anti-diuretic hormone (ADH) response and increased atrial natriuretic levels ${ }^{(8)}$.

The results showed that not fulfilled the amount of drinking water needed by the body will interfere with the kidney's work in regulating water balance, blood pressure, and the disposal of waste from the body. The kidneys should do metabolism to regular water, which aims to maintain a range of plasma osmolarity between 275 to $290 \mathrm{mOsm} / \mathrm{kg}$. The occurrence of an increase in the osmolarity of plasna, intracellular activation of osmoreceptor and also the baroreceptors in an extracellular basis stimulates the release of the hypothalamic arginine vasopressin or AVP that works in the kidneys to suppress the volume of urine and increase the water retention and urine into hypertonic. The decrease in plasma osmolarity resulting in the release of AVP to be obstructed, the kidneys will increase hypotonic output so that the kidneys require adequate water to regulate the balance of kidney fluid, filtering waste from the blood stream and its excretion through urine ${ }^{(9)}$. The aging process can result in normal changes that could potentially increase the risk of dehydration as a result of lack of response to the thirst perceived by CKD sufferers resulting in an increase in antidiuretic hormone levels, but a decline in the ability of nephrons in performing storage against water as a response to anti-diuretic hormone or $\mathrm{ADH}$ and elevated natriuretic atrial levels ${ }^{(8)}$. Lack of fluid intake by the body that causes dehydration will reduce renal performance and decrease renal function, thus causing the incidence of $\mathrm{CKD}^{(10)}$.

The results showed that diabetes mellitus, systolic blood pressure and diastolic blood pressure had a significant effect on the incidence of $\mathrm{CKD}$ in public transportation drivers in Jember District. The results showed that there was an influence on the history of diabetes mellitus with the incidence of CKD on public transportation drivers in Jember District. The results of this study are in line with research conducted by Sulistiowati \& Idaiani which states that, diabetes influences the incidence of CKD, where respondents in their 
study who had diabetes mellitus were 2.5 times more likely to suffer CKD compared to respondents who did not suffer from diabetes mellitus ${ }^{(11)}$. Hengkesa \& Lawalata states that, diabetes mellitus is a risk factor for CKD with an OR value of $5.134^{(12)}$.

The results of the study prove that systolic blood pressure significantly influences the incidence of CKD in public transportation drivers in Jember Regency. The results of this study are in line with research conducted by Sur et al. which proves that, systolic blood pressure is significantly associated with worsening kidney function $^{(13)}$. Diatolic blood pressure is blood pressure when the heart is relaxing. The results of the study prove that diastolic blood pressure has a significant effect on the incidence of CKD on public transportation drivers in Jember Regency. This study is in line with research conducted by Bae et al. which proves that, diatolic blood pressure affects the increased incidence of end-stage renal disease ${ }^{(14)}$. Hypertension or high blood pressure is a major cause of CKD. High blood pressure can stretch the blood vessels so that blood flow is easier to flow but stretching these blood vessels will injure and weaken blood vessels throughout the body including blood vessels found in the kidneys.

This study uses the characteristics of the individual's age, years of service, nutritional status, skinfold thickness, physical activity, smoking habits and habits of consuming alcoholic beverages as variables. The results showed that age, nutritional status, physical activity, smoking habits and habits of consuming alcoholic drinks had a significant effect on the incidence of CKD, while years of service and skinfold thickness had no effect on the incidence of CKD on public transportation drivers in Jember District. Smoking is one of the factors that influence the occurrence of CKD in the workplace, the results of the study indicate that there is a significant influence between smoking habits on the incidence of CKD on public transportation drivers in Jember Regency. Most CKD sufferers are public transportation drivers in Jember District who do not have the habit of smoking, but there are drivers who have a heavy smoking habit or who spend more than 20 cigarettes per day. Smoking habits in this study had a negative influence on the incidence of CKD on public transportation drivers in Jember District $(\mathrm{B}=-1.039$ ) because most of the drivers suffering from CKD were drivers who did not have a smoking habit (44.4\%), but most of the drivers nonsmokers are drivers who do not suffer from CKD (55.6\%).

The habit of consuming alcoholic drinks is one of the factors that influence the occurrence of CKD in the workplace, the results of the study indicate that there is a significant influence between the habit of consuming alcoholic beverages on the occurrence of CKD on public transportation drivers in Jember Regency. Most CKD sufferers are public transportation drivers in Jember who consume alcoholic drinks in the frequent category. This is in line with research conducted by Pan et al. who concluded that, alcohol-related disorders were associated with an increase in the incidence of newly diagnosed CKD nearly doubled, and had a higher effect on someone who was young ${ }^{(15)}$. States, the habit of consuming alcoholic beverages is also related to the cause of death in patients with $\mathrm{CKD}^{(16)}$. National Kidney Foundation states, alcohol can affect many organs of the body, including the kidneys. The highest risk of CKD is in someone who has the habit of consuming alcoholic beverages and also smoking, the kidneys that function as filters of harmful substances such as alcohol so that the kidneys work harder in people who consume alcoholic beverages ${ }^{(17)}$.

The results of this study are in line with the research of Reilly who mentioned that, chronic lead exposure was associated with deteriorating kidney function in African American men and women as well as male workers in the Dallas smelter, the study had a low but statistically insignificant effect ${ }^{(18)}$. This study also contradicts the research of Mulyadi which proves that, blood lead levels are influenced by lead exposure in the air, while Hemoglobin and Cystatin $\mathrm{C}$ are affected by blood lead levels so lead levels in the blood cause haematological disorders and disorders of the kidneys ${ }^{(19)}$. Laboratory examination results of lead blood levels of drivers included in the normal category are blood lead levels $<5 \mu \mathrm{g} / \mathrm{dL}$. Lentini states, acute lead exposure is indicated by blood lead levels of $\geq 50 \mu \mathrm{g} / \mathrm{dL}$, while the lowest lead level in the blood of the driver is $0.75 \mathrm{mg} / \mathrm{kg}$ or 75 $\mu \mathrm{g} / \mathrm{dL}$ and the highest lead level in the blood of the driver is $4.87 \mathrm{mg} / \mathrm{kg}$ or $487 \mu \mathrm{g} / \mathrm{dL}$ so it can be concluded that, most drivers can be said to have experienced acute exposure to lead ${ }^{(20)}$.

The most influential factor on the occurrence of CKD on public transportation drivers in Jember Regency is physical workload. This is due to the fact that the physical workload has the highest risk of 38.092 compared to other factors that have been issued automatically in the multivariate model. The magnitude of risk is 38,092 which means that drivers with moderate physical workload have a risk of 38.092 times greater CKD compared to drivers withworkload physical with normal and light categories, while physical workloads with normal and light categories will reduce the risk of CKD on public transportation drivers in Jember Regency.

The physical workload on the driver will affect the physical activity carried out by the driver when the driver is working so as to result in not meeting the body's need for fluid in the driver which causes a decrease in plasma osmolality which is $<275 \mathrm{mOsm} / \mathrm{kg}$ which can interfere with the release of the hypothalamus arginine vasopressin (AVP), AVP works in the kidney to reduce urine volume and increase water retention and urine becomes hypertonic, decreased plasma osmolality results in inhibition of AVP release and the kidney increases hypotonic output ${ }^{(21)}$. 


\section{CONCLUSION}

The conclusion are:

1) Physical workload, the level of drinking water consumption and the level of dehydration has a significant effect on the incidence of CKD.

2) The history of the disease that has a significant effect on CKD are diabetes mellitus, systolic blood pressure and diastolic blood pressure.

3) The individual characteristics that significantly influence the incidence of CKD are age, nutritional status, physical activity, smoking habits and alcoholic consumption habits.

4) The most influential factor on the occurrence of CKD is physical labor burden.

\section{REFERENCES}

1. Ministry of Environment of The Republic of Indonesia. Air Pollution Standard Index data graphics (Grafik Data Indeks Standard Pencemaran Udara). Jakarta: Ministry of Environment of The Republic of Indonesia; 2019.

2. Agency for Toxic Substances \& Disease Registry. Lead $(\mathrm{Pb})$ Toxicity. ATSDR: Environmental Medicine and Environmental Health Education. [Internet]. 2019 [cited 2019 Aug 31]. available from: https://www.atsdr.cdc.gov/csem/csem.html

3. Aroem H. Picture of quality of life anxiety in patients undergoing hemodialysis (Gambaran Kecemasan dan Kualitas Hidup pada Pasien yang Menjalani Hemodialisa. Surakarta: UMS; 2015.

4. Roina E, Megawati. Factors affecting glomerular filtration rate (Faktor-Faktor yang Mempengaruhi Laju Filtrasi Glomerulus). [Internet]. 2010 [cited 2019 Sep 10]. Available from: http://repository.usu.ac.id/ handle/123456789/17405

5. Lieber. Alcoholic Fatty Liver: It's Pathogenesis and Mecanism of Progression to Inflammation and Fibrosis. Journal Alcohol PMID. 2004. DOI: 10.1016/j.alcohol.2004.07.008.

6. Raputra GH. Physical workload and total consumption of drinking water with dehydration rate (Hubungan Beban Kerja Fisik dan Jumlah Konsumsi Air Minum dengan Tingkat Dehidrasi) (Study on workers at the factory know UD Sumber Kencana Surabaya). Surabaya: UNAIR; 2016.

7. Yusuf S, Haris A, Kadim M. Overview of the degree of dehydration and impaired renal function in acute diarrhea (Gambaran Derajat Dehidrasi dan Gangguan Fungsi Ginjal pada Diare Akut). 2011. DOI: 10/14238/sp13.3.2011.221-5:221-225.

8. Kozier B, Glenora BA, Synder JS. Teaching book Fundamentals of Nursing concepts, processes and practices (Buku Ajar Fundamental Keperawatan Konsep, Proses dan Praktik). Jakarta: EGC; 2011.

9. Popkin BM, D'Anci KE, Rosenberg IH. Water, Hydration and Health. National Institute of Health. 2010;68(8):439-458.

10. Isroni L. Fluid management in hemodialysis patients to improve the quality of life. Ponorogo (Manajemen Cairan pada Pasien Hemodialisis untuk Meningkatkan Kualitas Hidup). Ponorogo: Unmuh Ponorogo Press; 2016.

11. Sulistiowati E, Idaiani S. Risk factors for chronic kidney disease based on analysis of Cross-Sectional Data Preliminary Study cohort disease not transmitted population aged 25-65 years in the village of Kebon Kelapa, Bogor City Year 2011 (Faktor Risiko Penyakit Ginjal Kronik berdasarkan Analisis CrossSectional Data Awal Studi Kohort Penyakit Tidak Menular Penduduk Usia 25-65 Tahun di Kelurahan Kebon Kelapa, Kota Bogor Tahun 2011). Buletin Penelitian Kesehatan. 2015;43(3):163-172.

12. Hengkesa P, Lawalata IV. Risk factors for chronic renal failure disease (Faktor Risiko Penyakit Gagal Ginjal Kronik). Molluca Medica. 2015;8(1):72-81.

13. Siagian KN, Damayanty AK. Identification of chronic kidney disease causes at age below 45 years in the hemodialysis Unit, Rasyida in Medan Kidney Hospital year 2015 (Identifikasi Penyebab Penyakit Ginjal Kronik pada Usia dibawah 45 Tahun di Unit Hemodialisis Rumah Sakit Ginjal Rasyida Medan Tahun 2015). Anatomica Medical Jurnal. 2018;1(3):159-166.

14. Bae EH, Lim SY, Han KD. Association between Systolic and Diatolic Blood Pressure Variability and the Risk of End-Stage Renal Disease. Hypertension. 2019;(74):880-887.

15. Pan CS, Ju TR, Lee CC. Alcohol use Disorder Tied to Development of Chronic Kidney Disease: A Nationwide Database Analysis. Plos One. 2018. DOI: https://doi.org/10.1371/journal.pone.0203410

16. Bundy JD, Bazzano LA, Xie D. Self-Reported Tobacco, Alcohol, and Illicit Drug Use and Progression of Chronic Kidney Disease. Clinical Journal of American Society of Nephrology. 2018;13(7):993-1001.

17. National Kidney Foundation. Drinking Alcohol Affects Your Kidneys. [Internet]. 2019 [cited 2019 Nov 12]. Available from: https://www.kidney.org/news/kidneyCare/winter10/AlcoholAffects 
18. Reilly R, Spalding S, Walsh B. Chronic Environmental and Occupational Lead Exposure and Kidney Function among African Americans: Dallas Lead Projecr II. International Journal of Environmental Research and Public Health. 2018. DOI 10.3390/ijerph15122875.

19. Mulyadi, Mukono HJ, Notopuro H. Exposure to lead air to blood, Hemoglobin, Cystatin C, car paint (Paparan Timbal Udara terhadap Timbal Darah, Hemoglobin, Cystatin C Serum Pekerja Pengecatan Mobil). Jurnal Kesehatan Masyarakat. 2018;11(1):87-95.

20. Lentini P, Zanoli L, Granata A. Kidney and Heavy Metals-The Role of Environmental Exposure (Review). AJKD. 2017;72(3):381-389.

21. Popkin BM, D'Anci KE, Rosenberg IH. Water, Hydration and Health. National Institute of Health. 2010;68(8):439-458. 